\title{
BROOKHGWEN
}

NATIONAL LABORATORY

BNL-75586-2006-CP

\section{LOCAL IMPACTS OF MERCURY EMISSIONS FROM COAL FIRED POWER PLANTS}

T.M. Sullivan, B. Bowerman, J. Adams, L. Milian, F. Lipfert, S. Subramaniam, and R. Blake

Presented at

Air Quality $V$

Washington, D.C.

September 21-23, 2005

November 2005

\author{
Environmental Sciences Department \\ Environmental Research \& Technology Division \\ Brookhaven National Laboratory \\ P.O. Box 5000 \\ Upton, NY 11973-5000 \\ www.bnl.gov
}

\begin{abstract}
Notice: This manuscript has been authored by employees of Brookhaven Science Associates, LLC under Contract No. DE-AC02-98CH10886 with the U.S. Department of Energy. The publisher by accepting the manuscript for publication acknowledges that the United States Government retains a non-exclusive, paid-up, irrevocable, world-wide license to publish or reproduce the published form of this manuscript, or allow others to do so, for United States Government purposes.
\end{abstract}

This preprint is intended for publication in a journal or proceedings. Since changes may be made before publication, it may not be cited or reproduced without the author's permission. 


\section{DISCLAIMER}

This report was prepared as an account of work sponsored by an agency of the United States Government. Neither the United States Government nor any agency thereof, nor any of their employees, nor any of their contractors, subcontractors, or their employees, makes any warranty, express or implied, or assumes any legal liability or responsibility for the accuracy, completeness, or any third party's use or the results of such use of any information, apparatus, product, or process disclosed, or represents that its use would not infringe privately owned rights. Reference herein to any specific commercial product, process, or service by trade name, trademark, manufacturer, or otherwise, does not necessarily constitute or imply its endorsement, recommendation, or favoring by the United States Government or any agency thereof or its contractors or subcontractors. The views and opinions of authors expressed herein do not necessarily state or reflect those of the United States Government or any agency thereof. 


\section{LOCAL IMPACTS OF MERCURY EMISSIONS FROM COAL FIRED POWER PLANTS}

T.M. Sullivan, B. Bowerman, J. Adams, L. Milian, F. Lipfert, S. Subramaniam, and R. Blake

Presented at Air Quality V

September, 2005

Washington, D.C. 


\title{
LOCAL IMPACTS OF MERCURY EMISSIONS FROM COAL FIRED POWER PLANTS
}

\author{
T.M. Sullivan ${ }^{1 *}$, B. Bowerman ${ }^{1}$, J. Adams ${ }^{1}$, L. Milian ${ }^{1}$, F. Lipfert ${ }^{2}$, S. Subramaniam ${ }^{3}$, and R. \\ Blake $^{4}$ \\ 1 Brookhaven National Laboratory, Upton, NY 11973 \\ 2 Private Consultant, Northport, NY, 11768 \\ 3 Miles College, Fairfield, AL, 35064 \\ 4 New York City College of Technology, Brooklyn, NY, 11201
}

\begin{abstract}
Mercury is a neurotoxin that accumulates in the food chain and is therefore a health concern. The primary human exposure pathway is through fish consumption. Coal-fired power plants emit mercury and there is uncertainty over whether this creates localized hot spots of mercury leading to substantially higher levels of mercury in water bodies and therefore higher exposure. To obtain direct evidence of local deposition patterns, soil and vegetations samples from around three U.S. coal-fired power plants were collected and analyzed for evidence of hot spots and for correlation with model predictions of deposition. At all three sites, there was no correlation between modeled mercury deposition and either soil concentrations or vegetation concentrations. It was estimated that less than $2 \%$ of the total mercury emissions from these plants deposited within $15 \mathrm{~km}$ of these plants. These small percentages of deposition are consistent with the literature review findings of only minor perturbations in environmental levels, as opposed to hot spots, near the plants. The major objective of the sampling studies was to determine if there was evidence for hot spots of mercury deposition around coal-fired power plants. From a public health perspective, such a hot spot must be large enough to insure that it did not occur by chance, and it must increase mercury concentrations to a level in which health effects are a concern in a water body large enough to support a population of subsistence fishers. The results of this study suggest that neither of these conditions has been met.
\end{abstract}

\section{INTRODUCTION}

Mercury is a neurotoxin that accumulates in the food chain and is therefore a health concern. Concentrations of mercury in the air are of little direct health concern. However, mercury in the air falls onto the Earth's surface through dry and wet deposition processes. This mercury can enter water bodies where a small percentage $(<10 \%)$ is transformed to methyl mercury. This chemical form of mercury readily enters the food chain and bioaccumulates. Upper trophic level fish can have mercury concentrations several orders of magnitude greater than that found in the water. As mercury accumulates in these organisms, ecological risks occur and potentially human health risks may occur through fish consumption.

On March 15, 2005, EPA issued the Clean Air Mercury Rule (CAMR) that included a market-based cap and trade program that, if implemented, would reduce nationwide utility emissions of mercury in two phases. Emissions would be capped at 38 tons per year by 2010 
and 15 tons per year in 2018. When fully implemented mercury emissions would be reduced by 33 tons per year from current levels (nearly 70 percent).

There are technical doubts pertaining to local deposition of mercury leading to hot spots. This has received widespread attention in the literature (ES\&T, 2004a, b, c). The following are selected quotes from public health officials and the popular press in the past year.

- "Unlike most pollutants, mercury is highly toxic and does not disperse easily, creating hot spots of contamination." (Kathleen McGinty, Director of Pennsylvania Department of Environmental Protection, July 2, 2004. (http://www.dep.state.pa.us/newsletter/default.asp?NewsletterArticleID=8850\&SubjectI $\underline{D}=)$

- "Specifically, we are concerned that local hot spots of elevated mercury may result or worsen, especially if the required reduction levels are not sufficiently strict." (Renee Cipriano. Director of Illinois Environmental Protection Agency, February 26, 2004 (Testimony to the U.S. EPA regarding the U.S. Environmental Protection Agency's Proposal to Control Emissions of Hazardous Air Pollutants from Utilities (January 30, 2004, 69 Federal Register 4652) Docket ID No. OAR 2002-0056.

- "We generally support market-based approaches such as cap and trade schemes, yet we have an equally strong objection to the exclusive use of cap and trade schemes where local emissions hot spots are a concern. While mercury pollution and emissions are widespread, indeed a global problem, we share the concerns of many states that EPA's proposed rule understates the needs for local controls as well", letter from Stephen Mahfood, Director Missouri Department of Natural Resources to Michael Leavitt, Director U.S. EPA.

- "Sulfur dioxide is light, and travels long distances; power plants in the Midwest can cause acid rain in Maine. So a cap on total national emissions makes sense. Mercury is heavy; much of it precipitates to the ground near the source. As a result, coal-fired power plants in states like Pennsylvania and Michigan create hot spots - chemical Chernobyls where the risks of mercury poisoning are severe. ... That probably means thousands of children will be born with preventable neurological problems." Paul Krugman, New York Times, p. A-23, April 6, 2004.

- After passing the rule, "Jeffrey R. Holmstead, head of the EPA's Office of Air and Radiation, said the rule would eliminate hot spots, or high mercury levels, in lakes and streams near big power plants." Tom Hamburger and Allan C. Miller, LA Times, March $16,2005$.

- "Hot spots are a concern with me," said John A. Paul, a Republican environmental regulator and fisherman in Ohio who served as co-chairman of an EPA advisory committee on mercury. "I advise anyone who eats fish caught in a lake or a stream near a power plant that they are at risk, and that this rule will do nothing to protect them - and might make things worse." Tom Hamburger and Allan C. Miller, LA Times, March 16, 2005.

- "A cap-and-trade program for mercury further dilutes an already weak rule and creates the risk of perpetuating dangerous mercury hotspots that threaten the health of our communities and children," said Department of Environmental Protection (DEP) Commissioner Bradley M. Campbell. May 18, 2005 Press Release form Peter C. Harvey, Attorney General, New Jersey. (http://nj.gov/lps/newsreleases05/pr20050518c.html) 
After issuing the CAMR rule, 14 states joined with several environmental advocacy groups to sue the EPA in the court of appeals asking that EPA rewrite the regulations to require that all plants install the best available technology for cutting mercury pollution within the next three years. In the lawsuit, the states charge that allowing plants to trade credits rather than mandating that they reduce emissions will lead to mercury hot spots around polluting plants. In addition the lawsuit requested that the court set aside the CAMR until the arguments on installation of the best technology could be heard. On August 5, 2005 the court of appeals denied the request to declare the regulation void but will hear arguments on the case.

\subsection{Defining a Hot Spot}

Although the term hot spot appears frequently in the health and environmental literature, precise definitions do not. Generally speaking, a hot spot is a spatial anomaly, i.e., a location whose properties exceed those generally expected in the area. In statistical terms, a hot spot is a location whose properties exceed more than about 2 or 3 standard deviations above the relevant mean. Methods to statistically define a hot spot for metals in soils generally compare the data to a log normal distribution and look for variations between the two (Tobias, 1997).

In general, for environmental mercury concentrations, it is difficult to determine the incremental effects of pollution due to the range in mercury concentrations found naturally. In areas that are not exposed to a mercury source, soil concentrations are often log-normally distributed (skewed towards high values. To determine the effects of additional pollution requires knowledge of the natural distribution of mercury (background) prior to the pollution events. For soils, this information is not available. Adding additional mercury from a pollution source that only changes the distribution slightly can best be evaluated through statistical measures.

Although a large point-source of $\mathrm{Hg}$ indeed constitutes an emission hot spot, it does not necessarily constitute a fetal exposure hot spot. In addition to the substantial global background in $\mathrm{Hg}$ air concentrations and deposition, the following processes act to smooth out spatial anomalies:

- Atmospheric variability, including winds and precipitation.

- Re-emission of mercury from vegetation and water bodies.

- Terrestrial leaching and washout in transferring watershed deposits into water bodies.

- Aquatic mixing within water bodies.

- Variability among fish species.

In order for a local $\mathrm{Hg}$ deposition to pose a risk to a developing fetus, its mother must routinely consume high-Hg fish from an affected water body for several months, probably at the rate of several fish meals per week. While this scenario is unlikely, it also requires a substantial fish population, which requires a substantial body of water, say of the order of tens of square $\mathrm{km}$. In developing the CAMR, EPA suggested that a "power plant may lead to a hot spot if the contribution of the plant's emissions of mercury to local deposition is sufficient to cause blood $\mathrm{Hg}$ levels of highly exposed individuals near the plant to exceed the Reference Dose (RfD). More specifically, EPA defined a "utility hotspot" as " a waterbody that is a source of consumable fish with Methylmercury tissue concentrations, attributable 
solely to utilities, greater than the EPA's Methylmercury water quality criterion of 0.3 $\mathrm{mg} / \mathrm{kg}$." (EPA, 2005a). EPA believes that utility attributable hotspots will not be an issue under the CAMR (EPA 2005b).

This study examined the possibility that coal-fired power plants act as local sources leading to mercury hot spots through examination of soil and vegetation samples from around three U.S. coal-fired power plants. One plant is a mid-size plant in the midwest that burns locally mined lignite. This site will be referred to as Plant A. The second plant is the Kincaid power plant located southeast of Springfield IL that was studied in the 1970's (Anderson et al., 1977) for increases in mercury content in the soil, sediment, air, and fish. In addition, tracer studies were performed on the emissions from this plant and measured concentrations were compared with predictions by the ISCST computer code (Cox, et al. 1986). This provides confidence that the ISCST models used in this study reasonably represent the plume at this site. The third plant is the Monticello plant located near Mt Pleasant, Texas. Historically, this coal plant has been among the top in mercury emissions in the country.

For this work, a hot spot was defined as a region in excess of at least five square kilometers in which the soil or vegetation mercury concentrations were elevated by more than two standard deviations above the mean. This definition is intended to determine hot-spots of a sufficient scale that it would meet the EPA definition of a utility hot spot. This study compares modeled patterns of mercury deposition with measured soil and vegetation mercury concentration patterns. Mercury concentration data were evaulated looking for revidence of hot spots. Comparisons between the data and the models were made to test the validity of the model.

\section{MODELING MERCURY DEPOSTION AROUND COAL-FIRED POWER PLANTS}

Studies of soils, sediments, and wet deposition around coal plants typically find some evidence of enhanced deposition; however, the impact and statistical significance of the results is generally weak with incremental deposition about $15 \%$ of background (Lipfert, 2004, Sullivan, 2005). Many of the coal plant studies (Klein et al. 1973, Anderson et al. 1977, Crockett et al. 1979, Kotnik, et al. 2000) were conducted in the 1970's when emission rates were higher due to fewer pollution controls and the use of coals with higher Hg content. In addition, these studies did not attempt to correlate modeled deposition with measured soil concentrations as done in this study.

Mercury deposition models are based on a number of assumptions and hence there is uncertainty in the predicted deposition rates. A key assumption in the models is that the mixture of reactive gaseous mercury (RGM) to elemental mercury $\mathrm{Hg}(0)$ is constant in the exhaust plume. However, recent experiments suggest that reactive gaseous mercury converts to $\operatorname{Hg}(0)$ quickly (Edgerton et al, 2004, Laudal et al, 2004). If the hypothesis is correct, then local impact of coal-fired power plants will be greatly reduced, since $\mathrm{Hg}(0)$ does not deposit as quickly as reactive gaseous mercury. In both studies, the measured fraction of RGM to $\operatorname{Hg}(0)$ in plumes was markedly lower than in the exhaust. 
The extant computer modeling suggests that increased deposition will occur on a local (2 to $10 \mathrm{~km})$ to regional scale $(20$ to $50 \mathrm{~km})$ with increases a small percentage of background deposition on the regional scale. (EPA, 1997, Sullivan, et al., 2001, Sullivan et al., 2003). The amount of deposition depends upon many factors including emission rate, chemical form of mercury emitted, other emission characteristics (stack height, exhaust temperature, etc), and meteorological conditions. Modeling suggests that wet deposition will lead to the highest deposition rates and that these will occur within a few $\mathrm{km}$ of the plant. The rates of dry deposition are are predicted to be less than for wet deposition, but they apply to a much greater area (Sullivan et al., 2003).

\subsection{Deposition Modeling}

The local atmospheric transport of mercury released from the coal-fired power plants was studied to estimate the local impacts of mercury deposition. The Industrial Source Code (ISCST3) Short Term air dispersion model was used to model these processes (EPA, 1995). This code is an updated version of the computer code used by the U.S. Environmental Protection Agency to examine local deposition from combustion sources in their report to Congress in 1998 (EPA, 1997).

Modeling deposition requires three key sets of parameters: source emissions rate, deposition parameters, and meteorological data. These are described in detail in Sullivan (2005). Mercury emissions data from each of the plants were used to represent the source terms. Deposition parameters were the same for all three plants and were consistent with values used by EPA in their report to Congress (EPA, 1997). The modeling was performed to determine if model results and environmental monitoring data both suggest that measured mercury levels in environmental media and biota may be elevated around coal fired power plants. The following sections summarize key data for deposition modeling.

\subsubsection{Emissions}

Three types of gaseous mercury species occur in the emissions and they behave differently. Elemental mercury, $\operatorname{Hg}(0)$, due to its high vapor pressure and low water solubility, is not expected to deposit close to the facility. In contrast, reactive gaseous mercury (RGM), $\mathrm{Hg}^{+2}$, is much more soluble in water and is accommodated in rain and therefore, will deposit in greater quantities closer to the emission sources. In addition, RGM will also undergo dry deposition at a much higher rate than elemental mercury. The third type of emission is in particulate form. Previous studies (Sullivan, et al. 2003) showed that for less than $2 \% \mathrm{Hg}(\mathrm{p})$, deposition was dominated by RGM with only a small contribution from $\mathrm{Hg}(0)$ over $30 \mathrm{~km}$ from the plant. The deposition is linearly proportional to source strength. Therefore, errors in the estimated amount of RGM will affect the total deposition, but not the deposition pattern. Due to emission controls at the power plants, less than $1 \%$ of the $\mathrm{Hg}$ is expected to be particulate form and this type of mercury was not modeled.

Power plant A features two units with a total generation capacity of nearly 1,200 megawatts. The plant first started generating electricity in 1979. The total emissions from the two stacks at Plant A were $344 \mathrm{~kg}$ or $1.210^{-2} \mathrm{~g} / \mathrm{s}$. Measured speciation data for Plant A indicated $82.2 \%$

$\mathrm{Hg}(0)$ and $17.8 \% \mathrm{Hg}^{+2}$. Using the fractional release rate from the test data, the release rate for each mercury category is $0.01 \mathrm{~g} / \mathrm{s}$ for $\mathrm{Hg}(0)$ and $0.002 \mathrm{~g} / \mathrm{s}$ for $\mathrm{Hg}^{+2}$. 
Total mercury emissions from the Kincaid power station were $161 \mathrm{~kg}(0.0051 \mathrm{~g} / \mathrm{s})$ in 2001 . Speciation data were not available, however other plants burning Powder River Basin coal generally emit $15-30 \%$ reactive gaseous mercury with the remainder $\mathrm{Hg}(0)$. For modeling purposes, a value of $20 \%$ reactive gaseous mercury and $80 \% \mathrm{Hg}(0)$ was selected. Based on these assumptions, emissions from Kincaid were $0.0041 \mathrm{~g} / \mathrm{s}$ for $\mathrm{Hg}(0)$ and $0.001 \mathrm{~g} / \mathrm{s}$ for $\mathrm{Hg}^{+2}$. Prior to 1997 a locally mined coal with higher mercury content was burned at this plant.

Total mercury emissions from the Monticello power station were $954.5 \mathrm{~kg}(0.0051 \mathrm{~g} / \mathrm{s})$ in 1999, the highest in the nation that year.. Speciation data from the Monticello plant suggested that $39.2 \%$ was $\mathrm{Hg}(0), 60.4 \%$ was $\mathrm{Hg}(+2)$, and $0.4 \%$ was $\mathrm{Hg}(\mathrm{p})$. Based on these assumptions, emissions from Monticello were $0.012 \mathrm{~g} / \mathrm{s}$ for $\mathrm{Hg}(0)$ and $0.018 \mathrm{~g} / \mathrm{s}_{\text {for }} \mathrm{Hg}^{+2}$.

\subsection{Deposition Modeling Results}

For Plant A, meteorological data for a five year period from the nearest airport, located about 40 miles away, were reviewed to determine wind patterns under dry and wet conditions. Under dry condtions, the prevailing winds ran along an axis from the northwest towards the southeast winds occurred regulary in each direction along this axis. Under wet conditions, winds were generally from the north and east. Deposition modeling of the emissions from the power plant (e.g. regional background was not modeled) predicted highest deposition rates within $10 \mathrm{~km}$ of the plant in a southwesterly direction. Modeled deposition is incorporated on maps with measued soil and vegetation values and will be presented later for all three plants. Total deposition rates were $3-10 \mathrm{ug} / \mathrm{m}^{2} / \mathrm{yr}$. The total background wet deposition in this region is expected to be $5-10 \mathrm{ug} / \mathrm{m}^{2} / \mathrm{yr}$. Dry deposition is likely to be about the same level. Thus, the plant may produce a region of a few tens of square kilometers with depostion at $15-100 \%$ above background. The region with predicted deposition rate more than $10 \_\mathrm{g} / \mathrm{m}^{2} / \mathrm{y}\left(100 \%\right.$ above background) is less than $1 \mathrm{~km}^{2}$ in area. The region with deposition rate above $3 \_\mathrm{g} / \mathrm{m}^{2} / \mathrm{y}$ ( $15 \%$ above background) is less than 20 $\mathrm{km}^{2}$. There are no lakes or major waterbodies in this small domain. Dry depostion rates were lower than wet depostion rates and were not predicted to be a major contributor to deposition in the region. Total deposition was dominated by RGM. Over the modeled domain, deposition of $\mathrm{Hg}(0)$ was a small fraction of the total deposition even though $82 \%$ of the emitted mercury is in this form. This site had the lowest predicted deposition of the three modeled sites primarily due to lower rainfall.

For Kincaid, meteorological data from the Springfield airport, located about 30 kilometers away, were reviewed for a five-year period to determine wind patterns under dry and wet conditions. Under dry condtions, the prevailing winds were primarily from the south. Winds occurred from the south $20 \%$ of the time. No other direction had winds more than $10 \%$ of the time. Under wet conditions, winds were generally from the south and north. However, precipitation also fell frequently when winds were out of the east.

Deposition modeling of the emissions from the power plant considered both dry and wet depositon; however, regional background was not modeled. Simulations were performed for the 5 year period from 1986 - 1990. Ths period included annual rainfall ranging from 24 to 46 inches and was representative of the range of condtions experienced in the region. From the results over five years, average annual deposition rates were calculated for both dry and 
wet deposition. Dry deposition is predicted to peak approximatley $18 \mathrm{~km}$ north of the plant at a rate of $0.6 \mathrm{ug} / \mathrm{m}^{2} / \mathrm{yr}$. The highest wet deposition rates were predicted within $10 \mathrm{~km}$ of the plant in a northerly direction. The predicted peak deposition rate was $18 \mathrm{ug} / \mathrm{m}^{2} / \mathrm{yr}$. The deposition rate remains above $5 \mathrm{ug} / \mathrm{m}^{2} / \mathrm{yr}$ for approximately 2 or $3 \mathrm{~km}$ around the plant and above $1 \mathrm{ug} / \mathrm{m}^{2} / \mathrm{yr}$ for 7 or $8 \mathrm{~km}$. For comparison, in the period of $1999-2003$, wet deposition (due to all sources including the regional background) averaged $9.3 \mathrm{ug} / \mathrm{m}^{2} / \mathrm{yr}$ at the nearest mercury deposition network (MDN) site in Bondville, IL which is approximatley $100 \mathrm{~km}$ west of the plant. Dry deposition is not well characterized but is expected to be approximately the same as wet depostion. If this is true, the predicted peak deposition near Kincaid would have total $\mathrm{Hg}$ deposition approximately twice background. Depostion rates resulting from Kincaid emissions would add less than $5 \%$ of background after $8 \mathrm{~km}$.

At the Monticello plant, over $98 \%$ of the deposition arises from reactive gaseous mercury. This is due to the large fraction of RGM (60\%) in the emissions and the large deposition rate parameters relative to elemental mercury. Meteorological data indicate that the wind flow is almost exclusively in the north-south direction and the predicted wet deposition is located along this axis. The large amount of RGM in the emissions leads to high predicted deposition rates. Wet deposition is predicted to be greater than $40 \mathrm{ug} / \mathrm{m}^{2} / \mathrm{yr}$ over a distance of five kilometers from the plant in both the north and south directions. The predicted region with excess deposition rate of $5 \mathrm{ug} / \mathrm{m}^{2} / \mathrm{yr}$ extends more than $50 \mathrm{~km}$ along the north-south axis. Wet deposition at the Longview Texas Mercury deposition network site, approximately 100 $\mathrm{km}$ southeast of Monticello ranged from $9.5-15.7 \mathrm{ug} / \mathrm{m}^{2} / \mathrm{y}$ over the period $1998-2003$. Thus, the predicted wet deposition within 5-10 kilometers of the plant along the north-south axis is $3-4$ times the regional background value.

\section{SOIL AND VEGETATION SAMPLING AND ANALYSIS}

\subsection{Sampling Design and Collection}

Based on the modeled deposition analysis at each sites, a soil and vegetation sampling design was selected. For Plant A, sampling was restricted to an $8 \mathrm{~km}$ square region to the south and west of the plant where modeled deposition was largest. The land surrounding the power plant was either part of an active strip mine or agricultural. Although many sampling sites were within the strip mine permit area, most of the land had been reclaimed. Strip mine personnel identified sites that had been fully reclaimed, or were at least known not to have been disturbed for at least a year. Agricultural area sampling sites were chosen in areas that were undisturbed for at least one year (i.e. had not been plowed or mowed). Due to a lack of correlation between modeled and measured concentrations at Plant $\mathrm{A}$, it was decided to sample in all directions around the Kincaid plant. A sampling area was increased to cover approximately $8 \mathrm{~km}$ in all directions. Samples were spaced approximately $1600 \mathrm{~m}$ (1 mile) apart. A total of 123 sample locations were selected. In addition, 8 additional sites were chosen with the intent of defining background. These sites were from $17.5-38 \mathrm{~km}$ from the power plant. The region around the plant is mostly open farmland. Lake Sangchris, a state park, is located directly to the north and east of the plant in the region of highest predicted deposition. At the Monticello plant, due to the higher emissions and resulting predicted higher deposition, the sampling domain was increased to $16 \mathrm{~km}$ in all directions. In all cases, sample locations were uniformly distributed over the sample area. A total of 102 sample locations were used within $16 \mathrm{~km}$ of the Monticello plant. In addition, 5 samples locations 
$20-40 \mathrm{~km}$ from the site were selected for background measurements. This plant was also adjacent to a large lake and state park.

At each location, three surface soil samples were collected. These samples were approximately 10 feet apart and were taken from the top $5 \mathrm{~cm}$ of soil. At the middle location a deep soil sample was taken from the $5-10 \mathrm{~cm}$ soil horizon and a vegetation sample was collected. Soil samples of approximately 100 grams weight were collected in watertight wide-mouth $250 \mathrm{~mL}$ plastic screw-top cups. Samples were collected using stainless steel trowels, which were rinsed with tap water and wiped dry between each use. Vegetation samples were collected using scissors to cut vegetation just above ground level. Blind field duplicates were collected every $10^{\text {th }}$ sample. Samples were shipped back to Brookhaven National Laboratory for analysis. Latitude and longitude for each sample location were identified using a GPS locator system with a resolution of 6 meters.

\subsection{Mercury Analysis Methods and Quality Assurance}

The soil samples were analyzed using a Direct Mercury Analyzer (DMA-80, Milestone, Inc, Monroe, CT). The DMA-80 can measure levels below $1 \mathrm{ppb}$ (ng/g). DMA-80 analyses were conducted on soil samples as received. Moisture content was determined separately for all samples, and mercury concentrations were adjusted to a dry weight basis.

Quality assurance was evaluated through taking blind duplicates of $10 \%$ of the samples, measurement of empty sample boats in the DMA-80, and use of one of two NIST mercury standards (SRM 2709 and SRM 2710) at every $10^{\text {th }}$ measurement. Blind duplicates were statistically similar to the similar soil samples. Each sample location was measured in triplicate to examine the homogeneity of the sample. The range of the mercury levels in the three samples averaged $+/-12.5 \%$ of the average of the three samples.

\subsection{Data Analysis and Interpretation}

At each sample location, the three surface soil samples were averaged to give a composite. In each case, the model predicts the incremental rate of deposition due to the coal plant emissions, while the measured data are soil concentrations, reflecting the effects of cumulative deposition, both local and regional, and the natural constituents of the soil. Therefore, a direct comparison between the modeled results and the measurements is not possible. However, if excess deposition were occurring in a region, it is expected that this would be reflected by higher soil concentrations.

The vegetation samples are a measure of mercury deposition over the current growing season. Vegetation mercury levels are known to be influenced by both wet and dry deposition of mercury. In sampling, every attempt was made to collect the same type of vegetation, grass, from each location. This was not always possible but samples were primarily grasses.

\subsubsection{Plant $A$}

Analysis of the data shows that they are log normally distributed, as would be expected for soil samples (Tack, 2005). At the fifty-four locations the average value was $27.6 \mathrm{ng} / \mathrm{g}$ (dry 
weight basis), with a standard deviation of 6.9. The minimum value was $11.6 \mathrm{ng} / \mathrm{g}$ and the maximum value was $55.4 \mathrm{ng} / \mathrm{g}$. All of the data were within approximately a factor of 2 of the average value thereby suggesting that 'hot spots' were not found in the soil near the plant. For example, the four highest values $(>36 \mathrm{ng} / \mathrm{g}) \mathrm{might}$ be hot spots, but only two are contiguous and none fall into the patterns predicted by modeling. Averaging each of these four values with their nearest neighbors, to simulate what might occur in a sizeable water body, reduces their magnitudes considerably to $5-13 \%$ above the median of all samples (27.5 $\mathrm{ng} / \mathrm{g}$ ), and do not constitute hot spots.

Comparison between the predicted deposition rates versus measured mercury concentrations in the soil was accomplished by overlaying the deposition map over the sampling map with sample results color-coded by measured concentration. Figure 1 is the graphical representation of the analysis. Sample locations are designated on the map with symbols representing measured mercury levels. Soil concentrations were binned into three approximately equal size groups. The range of the groups was $11.4-25.2,25.2-29.5$ and $29.5-55.4 \mathrm{ng} / \mathrm{g}$. One third of the soil $\mathrm{Hg}$ measurements were within the narrow range of $25.2-29.5 \mathrm{ng} / \mathrm{g}$. Predicted regions of enhanced deposition are covered by the filled contours with red representing $5 \mathrm{ug} / \mathrm{m}^{2} / \mathrm{yr}$ and blue representing $3 \mathrm{ug} / \mathrm{m}^{2} / \mathrm{yr}$.

Figure 1a shows that the patterns of modeled deposition and measured data do not match. The measured soil data suggest that the main finger of the plume is slightly south of the area predicted by modeling. Also, the measured data shows a fair degree of scatter, as expected in a natural distribution, in contrast to the smoothly varying deposition pattern. To evaluate if there was a match between the data and the model statistically, both were ordered from high to low and a rank correlation between the soil and predicted deposition was performed. The Spearman rank correlation coefficient was -0.02 indicating no correlation between the two.

A second approach to determining if excess deposition was occurring was to compare the concentrations of surface soil $(0-5 \mathrm{~cm})$ and subsurface soil $(5-10 \mathrm{~cm})$ collected at each sampling location. The subsurface samples showed similar values and characteristics as the surface samples. The Spearman Rank correlation coefficient between the surface and subsurface soil $\mathrm{Hg}$ concentrations is 0.77 indicating a high degree of correlation. Therefore, there is no evidence that local deposition increased the surface $\mathrm{Hg}$ soil concentrations relative to the subsurface soil.

The vegetation samples from around Plant A were analyzed in duplicate and the average value was taken as a measure of the $\mathrm{Hg}$ content for samples that were low in mercury and provided similar readings in both measures. Many samples showed high levels of $\mathrm{Hg}(>100$ $\mathrm{ng} / \mathrm{g}$ ) and wide variability in the measured value. These samples were analyzed between 3 and 7 times to improve the accuracy of the results. Details are provided in Sullivan, 2005.

Unlike the soil samples, the vegetation samples did show regions of elevated $\mathrm{Hg}$ concentration. Defining a high $\mathrm{Hg}$ concentration as any average value that is 3 times above the median value for all samples shows that 12 of 49 samples have 'high' concentrations. Individual samples were in excess of $1000 \mathrm{ng} / \mathrm{g}$. Although, there was wide variation in the measured mercury value for the vegetation with 'high' levels of mercury $(>100 \mathrm{ng} / \mathrm{g})$, these samples were consistently high in all of the samples. 
Figure $1 \mathrm{~b}$ presents the measured mercury concentration in vegetation and the predicted deposition. In Figure 1b, the blue contour represents excess deposition of $3 \mathrm{ug} / \mathrm{m}^{2} / \mathrm{yr}$ and the red represents $5 \mathrm{ug} / \mathrm{m}^{2} / \mathrm{yr}$. Soil vegetation samples were divided into four groups representing the range from $10.7-22.9 ; 22.9-31.5,31.5-84.4$; and $84.4-691 \mathrm{ng} / \mathrm{g}$. Each range represents approximately _ of all samples. In Figure $1 \mathrm{~b}$, the highest values are near the plant, primarily to the north and west. This is the primary direction of wind flow during dry deposition conditions. However, deposition modeling would predict that the peak deposition rates would occur further from the plant due to the stack height and buoyancy effects. All of the values in the top _ of the distribution are within $4000 \mathrm{~m}$ of the plant with the exception of one value located approximately $6500 \mathrm{~m}$ east of the plant. This site was selected to be out of the predicted deposition pattern and was hoped to be representative of background. Clearly it is not. Most of the very high vegetation $\mathrm{Hg}$ values are located adjacent to a coal transporter that was previously used to move coal from the mine to the plant.
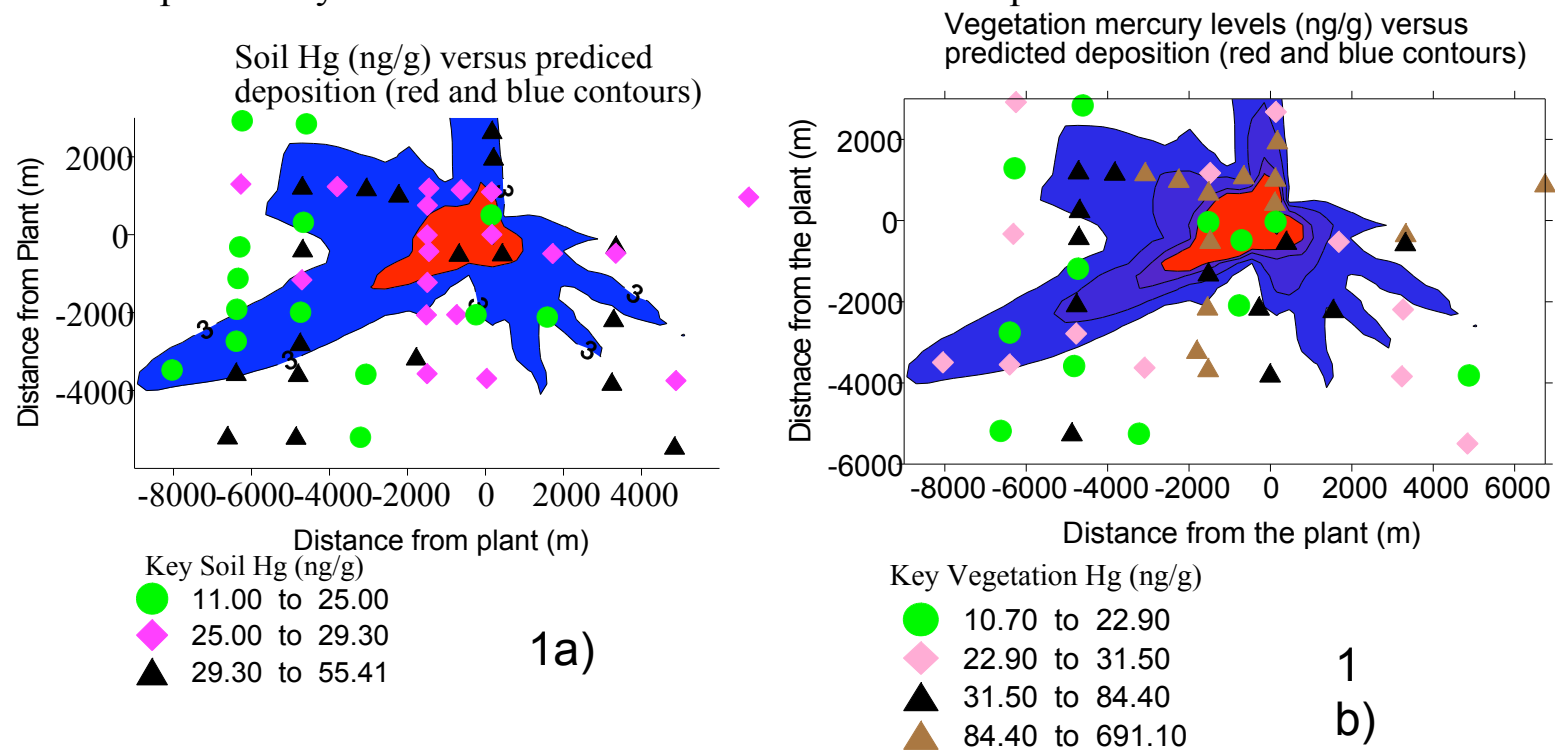

Figures 1a) and 1 b) - Measured Soil (1a) and Vegetation (1b) concentrations compared to predicted excess deposition near Plant A.

\subsubsection{Kincaid}

At the 124 locations around the plant, the average value was $32 \mathrm{ng} / \mathrm{g}$ (dry weight basis), with a standard deviation of $17.7(\mathrm{GSD}=1.34)$. The median value was $25.9 \mathrm{ng} / \mathrm{g}$. The minimum value at any location averaged over the six measurements was $16.9 \mathrm{ng} / \mathrm{g}$ and the maximum value was $155.6 \mathrm{ng} / \mathrm{g}$. The data showed a much wider distribution than for Plant A with a few values that were very high above the mean. Statistical analysis of the data (Sullivan, et al. 2005) showed that the data did not fit a lognormal distribution with the distribution skewed towards higher values above the mean. This could imply enhanced deposition, or it could imply differences due to different soils.

In examining the data, it appeared that there were several locations with values much higher than the mean. For the purposes of further analysis and data interpretation any location that had a soil mercury value that was more than a factor of 2 greater than at adjacent locations $(<$ 1 mile) was examined. A factor of 2 difference from nearest neighbors could not occur due to deposition only because the deposition rate does not change by a factor of two in less than a mile. Therefore, the change is likely due to having different soil properties. These sites 
had soil $\mathrm{Hg}$ values ranging from $56-155.6 \mathrm{ng} / \mathrm{g}$. Analysis of these potential hot spots was undertaken by focusing on the high values, in relation to their immediate neighbors. The top $3 \mathrm{Hg}$ concentrations values ranged from 2.6 to 5 times the median value of all samples. After averaging with all samples within 1.5 miles of the location with the high value (up to 8 neighboring samples), these excess soil $\mathrm{Hg}$ concentration ratios were reduced to $0.8,0.9$, and 1.5. Thus, only one location showed an excess of mercury when averaged over a larger area to simulate effects on watersheds.

Comparison between the predicted deposition rates versus measured mercury concentrations in the soil was accomplished by overlaying the deposition map over the sampling map with sample results color-coded by measured concentration. Figure $2 \mathrm{a}$ is the graphical representation of the analysis for the samples near the Kincaid plant. Soil concentrations were binned into four approximately equal size groups containing 29 or 30 samples. Sample locations with symbols representing measured mercury levels represent the measured data. The range of the groups was $16.9-24.6,24.6-27.0,27.0-31.3$, and $31.3-65.2 \mathrm{ng} / \mathrm{g}$. The narrow spread of the middle groups around the average shows that $1 / 2$ of the soil $\mathrm{Hg}$ measurements were in the range of $24.6-31.3 \mathrm{ng} / \mathrm{g}$. Predicted regions of enhanced deposition are covered by the filled contours with red representing $10 \mathrm{ug} / \mathrm{m}^{2} / \mathrm{yr}$, purple representing $5 \mathrm{ug} / \mathrm{m}^{2} / \mathrm{yr}$, and blue representing $1 \mathrm{ug} / \mathrm{m}^{2} / \mathrm{yr}$.

Examining Figure 2a shows that there is not a particularly good correlation between regions of predicted enhanced deposition and soil $\mathrm{Hg}$ concentrations. Although higher concentrations do occur near the plant. In the region of predicted deposition in excess of 5 $\mathrm{ug} / \mathrm{m}^{2} / \mathrm{yr}, 6$ of 12 sample locations have soil $\mathrm{Hg}$ concentrations in the top quartile. However, four of these six locations are along a heavily traveled road, The highest measured concentration (with the outliers removed) $65.2 \mathrm{ng} / \mathrm{g}$ occurs at the location closest to the power plant, approximately 0.8 miles west of the plant.

Figure $2 \mathrm{~b}$ graphically represents the soil data, binned into the same four groups as in Figure $2 \mathrm{a}$ with a base map of the local roads. Examining this figure it appears that there is a correlation between soil $\mathrm{Hg}$ and the East-West sample locations along the road that passes immediately south of the power plant. This road was the busiest road in the sampling domain near the plant as it had all of the employee traffic, it connected the two nearest towns, and had an access ramp to the interstate to the west of the plant. In addition, samples in the lowest quartile were frequently associated with roads carrying less traffic.

Comparison of the surface $(0-5 \mathrm{~cm})$ samples with the deep samples $(5-10 \mathrm{~cm})$ at the same locations showed a strong correlation between the two. The Spearman rank correlation coefficient between the surface and deep soils was 0.78 indicating a strong correlation. The average of the deep soils was $0.6 \mathrm{ppb}$ less than for the surface soils. However, this was not statistically significant.

Attempts to define background were based on taking soil samples from eight locations at distances of $11-23$ miles from the plant. Each location was predicted to be well outside the domain of influence for enhanced mercury deposition from the plant. The background sites 

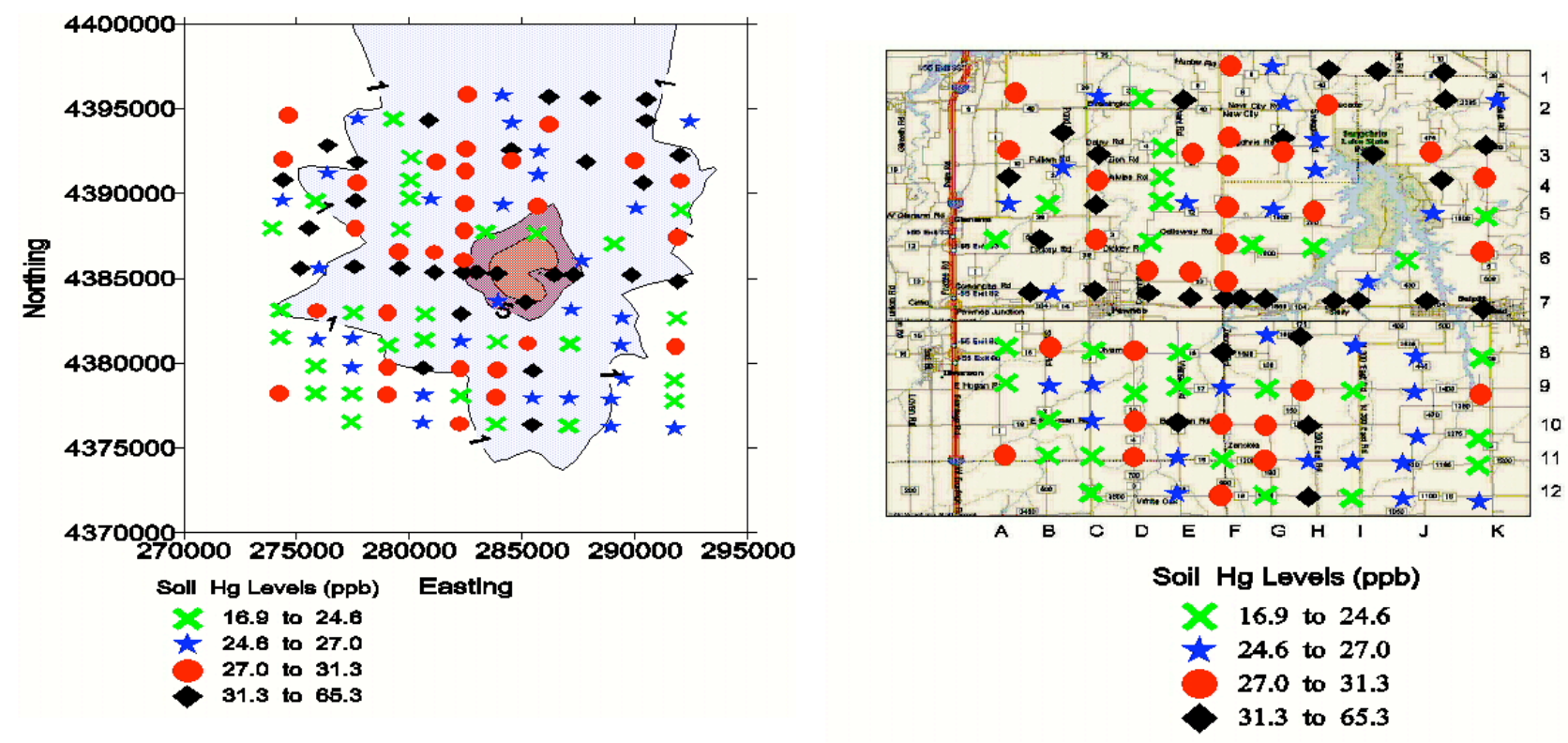

Figure 2 - a) Comparison of measured soil $\mathrm{Hg}$ values (ng/g)with predicted deposition filled contours. b) Measured soil Hg (ng/g) on a street map near the Kincaid plant.

had higher mercury levels than those near the plant with 4 of the 8 sites above $40 \mathrm{ng} / \mathrm{g}$ level. The background sites were selected on fairly well traveled roads for ease of access. Near the plant, higher mercury levels did seem to be associated with higher levels of traffic. The average of all background sites was $40.5 \mathrm{ng} / \mathrm{g}$, close to the average value along the higher road south of the plant, $41.0 \mathrm{ng} / \mathrm{g}$. The locations may partially explain the higher mercury values associated with the background sites. In any event, the background samples could not be used to estimate a regional background.

The measured $\mathrm{Hg}$ vegetation concentrations also showed poor agreement with the predicted deposition. Soil vegetation concentrations were much lower than in the soil and ranged from $0.6-22.5 \mathrm{ng} / \mathrm{g}$. The median value was $4.8 \mathrm{ng} / \mathrm{g}$ and the average value was $5.7 \mathrm{ng} / \mathrm{g}$ with a standard deviation of $3.8 \mathrm{ng} / \mathrm{g}$. The highest vegetation $\mathrm{Hg}$ locations are approximately 6 miles from the plant and are not in the region of predicted high deposition. The correlation of high $\mathrm{Hg}$ values along the busiest road was not found in the vegetation samples.

\subsubsection{Monticello}

A total of nine values (3 locations and triplicate measures at each location) were used to estimate the average at each sample location. At the 102 locations around the plant, the average value was $33.5 \mathrm{ng} / \mathrm{g}$ (dry weight basis), with a standard deviation of 18.0 . The median value was $28.5 \mathrm{ng} / \mathrm{g}$. The minimum value at any location averaged over the nine measurements was $7.6 \mathrm{ng} / \mathrm{g}$ and the maximum value was $111.4 \mathrm{ng} / \mathrm{g}$. The data values were very similar to those found at the Kincaid site.

Figure 3a presents the measured soil concentrations and the predicted deposition contours o a base map of the Monticello area. Measured sol concentrations were grouped into 4 equal sized bins ranging from 7.6 - 21.7, $21.7-28.4,28.4-40.4$, and $40.4-111.5 \mathrm{ng} / \mathrm{g}$. Predicted deposition contours extend over an area greater than $20 \mathrm{~km}$ from the plant at levels of 10 $\mathrm{ug} / \mathrm{m}^{2} / \mathrm{yr}$. The highest contour, $40 \mathrm{ug} / \mathrm{m}^{2} / \mathrm{yr}$, lies along the north-south axis for approximately $10 \mathrm{~km}$ centered on the plant. Again, the predicted deposition pattern does not match the 
measured soil $\mathrm{Hg}$ pattern well. Values in the upper $25 \%$ of the soil $\mathrm{Hg}$ distribution $(\mathrm{Hg}>$ $40.4 \mathrm{ng} / \mathrm{g}$ ) tended to be close to the lake. In reviewing the soil characteristics, soils with high levels of mercury tended to be brown or dark brown in color while those with low mercury levels were gray or light brown and sandy. The dark brown color suggests a higher organic content in these soils and mercury is known to preferentially accumulate in organic matter. However, the organic content has not been determined. As at the other two sites, there was a strong correlation between surface and deep samples, further supporting the importance of soil characteristics as controlling mercury levels. At Monticello, the deep samples averaged slightly greater mercury levels than the surface samples, but the difference was not statistically significant.
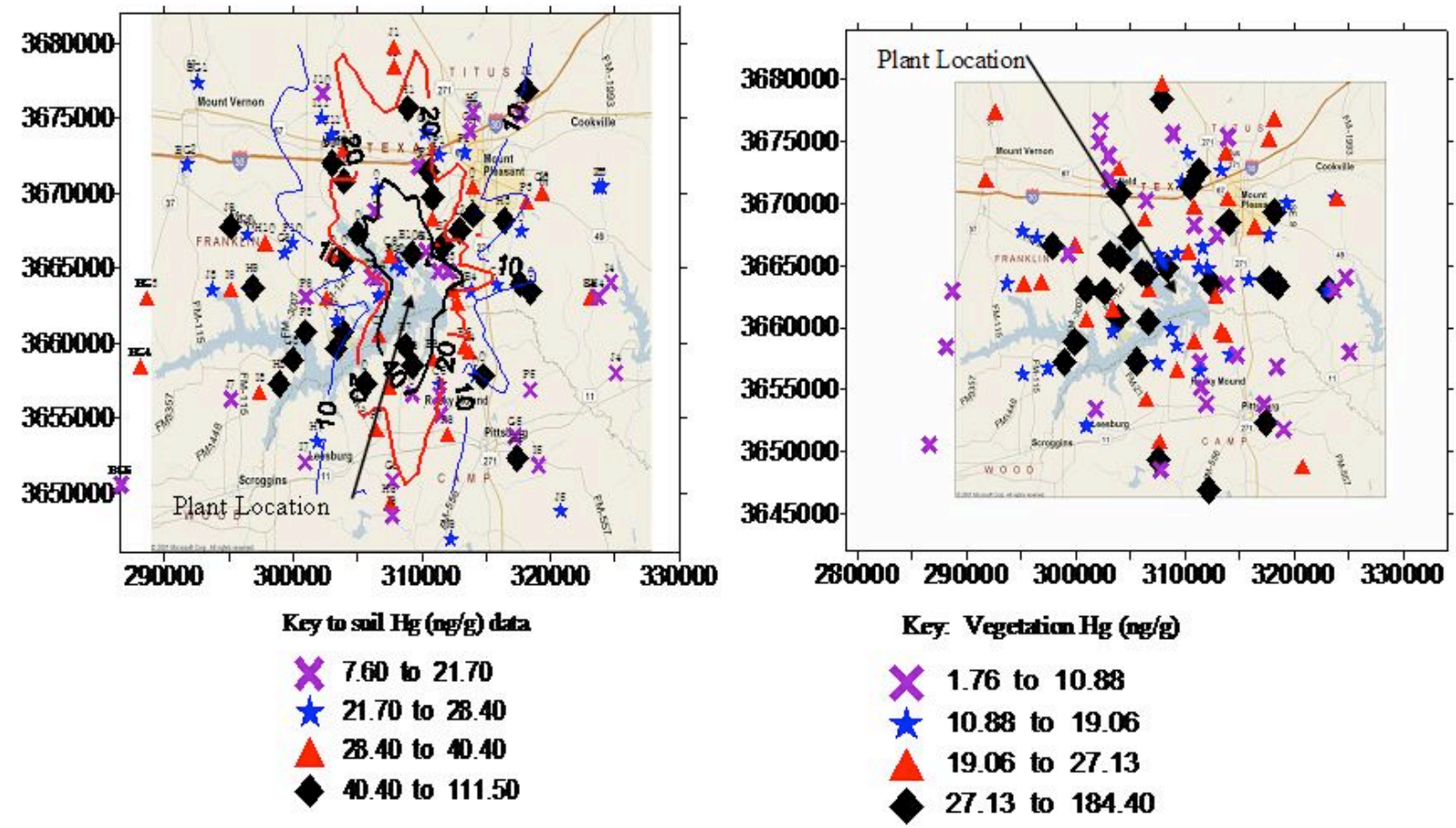

Figure 3 a) Measured soil Hg (ng/g) concentrations with predicted deposition contours, and b) Measured vegetation $\mathrm{Hg}(\mathrm{ng} / \mathrm{g}$ ) concentrations near the Monticello Plant.

Figure $3 \mathrm{~b}$ shows the vegetation $\mathrm{Hg}$ concentrations around the Monticello site. There was a good correlation between high mercury in the soil and vegetation. The spread in the data for vegetation was larger than for soil, perhaps reflecting a wider range of vegetation types. At this site, vegetation ranged from grass covered soils to nearly bare soils with a few weeds. It was not possible to collect grass samples from all sites.

\section{CONCLUSIONS}

A thorough quantitative understanding of the processes of mercury emissions, deposition, and translocation through the food chain is currently not available. Complex atmospheric chemistry and dispersion models are required to predict concentration and deposition contributions, and aquatic process models are required to predict effects on fish. There are uncertainties in all of these predictions. Therefore, the most reliable method of understanding impacts of coal-fired power plants on $\mathrm{Hg}$ deposition is from empirical data. 
Soil and vegetation sampling programs were performed around three coal fired power plants. The objectives were to determine if local mercury hot spots exist, to determine if they could be attributed to deposition of coal-fired power plant emissions, and to determine if they correlated with model predictions. The sampling programs found the following:

- At all three sites, there was no correlation between modeled mercury deposition and either soil concentrations or vegetation concentrations. At the Kincaid plant, there was excess soil $\mathrm{Hg}$ along heavily traveled roads. At the Monticello plant, excess soil $\mathrm{Hg}$ was associated with soil characteristics.

- At all three sites, the subsurface $(5-10 \mathrm{~cm})$ samples the $\mathrm{Hg}$ concentration correlated strongly with the surface samples $(0-5 \mathrm{~cm})$. Average subsurface sample concentrations were slightly less than the surface samples at two sites and slightly greater at one site, however, the differences were not statistically significant.

- An unequivocal definition of background $\mathrm{Hg}$ was not determined at any site. Based on computer modeling, $\mathrm{Hg}$ deposition was primarily RGM with much lower deposition from elemental mercury. Deposition rates from emissions from coal-fired power plants were on the order of background levels for a few tens of square kilometers at Plant $\mathrm{A}$ to a few hundred square kilometers at Monticello. However, doubling of soil or vegetation concentrations were not observed in the predicted deposition zones. Estimates of the percentage of total $\mathrm{Hg}$ deposition ranged between 0.3 and $1.7 \%$. These small percentages of deposition are consistent with other empirical findings of only minor perturbations in environmental levels, as opposed to hot spots, near the plants.

The major objective of this study was to determine if there was evidence for hot spots of mercury deposition around coal-fired power plants. From a public health perspective, such a hot spot must be large enough to insure that it did not occur by chance, and it must affect water bodies large enough to support a population of subsistence fishers. The results of this study indicate that these conditions have not been met.

\section{REFERENCES}

Anderson WL, Smith KE. Dynamics of Mercury at a Coal-Fired Power Plant and Adjacent Cooling Lake, Environ Sci Tech,(1977),11:75-80.

Cox WM., Rorex HW, Moss GK. Evaluation of Rural Air Quality Simulation models, Addendum C: Kincaid $\mathrm{SO}_{2}$ Data Base, EPA-450/83-003c, U.S. Environmental Protection Agency, Research Triangle Park, NC, March 1986.

Crockett A., Kinnison RH. Mercury Residues in Soil around a Large Coal-Fired Power Plant, Environ Sci Tech (1979) 13:712-5.

Edgerton E, Hartsell B, Jansen J. "Hg Speciation in Coal-Fired Power Plant Plumes: Evidence for Reduction of RGM to HG(0)," $7^{\text {th }}$ Annual Conference on Mercury as a Global Pollutant, Ljubljana, Slovenia, July 2, 2004. 
U.S. Environmental Protection Agency, User's Guide for the Industrial Source Complex (ISC3) Dispersion Models, Volume I - User Instructions, EPA-454/B-95-003A, Office of Air Quality Planning and Standards Emissions, Monitoring, and Analysis Division, Research Triangle Park, NC. 1995

U.S. Environmental Protection Agency, Fate and Transport of Mercury in the Environment, Mercury Study Report to Congress, vol. III, EPA-452/R-970995, 1997.

U.S. Environmental Protection Agency, State Mercury Emissions Estimates from Power plants, June 2001, http:/www.epa.gov/ttn/atw/combust/utiltox/utoxpg.html\#DA1.

U.S. Environmental Protection Agency, "Final Rule - Revision of December 2000 Regulatory Finding on the missions of Hazardous Air Pollutants from Electric Utility Steam Generating Units and the Removal of Coal- and Oil-fired Electric Utility Steam Generating Units from the Section 112(c) List", 2005a. http://www.epa.gov/air/mercuryrule/pdfs/camr final regfinding.pdf

U.S. Environmental Protection Agency, "Final Rule Preamble - Standards of Performance for New and Existing Stationary Sources: Electric Utility Steam Generating Units, 2005b , T6560-50-P http://www.epa.gov/air/mercuryrule/pdfs/camr_final_preamble.pdf Environmental Science and Technology Science Page, "Controversial Results Downplay Power Plant Mercury Emissions," Nov. 3, 2004. http://pubs.acs.org/subscribe/journals/esthag-w/2004/nov/science/rr_mercury.html

Environmental Science and Technology Science Page, "Mercury Trading Scheme Raises Concern," March 4, 2004. http://pubs.acs.org/subscribe/journals/esthagw/2004/mar/science/kc_mercury.html

Environmental Science and Technology Policy Page, "Mercury Policy Debate Heats Up," July 28, 2004.

http://pubs.acs.org/subscribe/journals/esthag-w/2004/jul/policy/kc mercury.html

Klein DH, Russell P. Heavy Metals: Fallout around a Power Plant, Environ Sci Tech (1973) 7:357-8.

Kotnik J, Horvat M., Mandic V, Logar M. Influence of the Sostanj coal-fired thermal power plant on mercury and methyl mercury concentrations in Lake Velenje, Slovenia, Science Total Environ (2000), 259:85-95.

Laudal D, Dunham G, Levin L. Mercury Control Technology R\&D Review, Pittsburgh, PA, July $14-15,2004$.

http://www.netl.doe.gov/publications/proceedings/04/HgReview/Laudal2.Presentation $\% 20 \mathrm{fo}$ r\%20Project $\% 20$ Review $\% 20$ Meeting\%20Plume $\% 20$ Study $\% 20$ -

\%20Pittsburgh $\% 20 J u l y \% 2014-15 \% 202004 \% 20-\% 202$.pdf

Lipfert, F., Sullivan, T., and Rennigner, S. "Assessing the Mercury Health risks Associated with Coal-Fired Power Plants: Issues in Atmospheric Processes." ACS Symposium on 
Mercury Measurement, Transformations, Control, and Related Issues in Power Systems, Anaheim, CA, March 28-April 1, 2004.

Mercury Deposition Network, http://nadp.sws.uiuc.edu/mdn.

Menounou N, Presley BJ. Mercury and other trace elements in sediment cores from central Texas lakes, Arch Environ Contam Toxicol (2003), 45:11-29.

Sullivan TM, Lipfert FD, Morris SC, Moskowitz PD. Potential Health Risk Reduction Arising From Reduced Mercury Emissions from Coal-Fired Power Plants, FY 2001 Report, September, 2001, BNL-71538-2003.

Sullivan TM, Lipfert FD, Morris SM. The Local Impacts of Mercury Emissions from Coal Fired Power Plants on Human Health Risk, Progress Report for the Period of March 2002 March 2003, BNL-71554-2003, May 2003.

Sullivan TM, Bowerman B, Adams J, Lipfert FD, Morris SM, Bando A, Pena R, Blake R. Mercury Emissions from Coal Fired Power Plants: Local Impacts on Human Health Risk, BNL topical report May, 2005.

Tack FMG, Vanhaesebroeck T, Verloo MG, Van Rompaey K, Van Ranst E. Mercury baseline levels in Flemish soils (Belgium), “Environmental Pollution (2005),134:173-179.

Tobias FJ, Bech J, Sanchez Algarra P. Statistical Approach to Discriminate Background and Anthropogenic Input of Trace Elements in Soils of Catalonia, Spain, Water Air and Soil Pollution (1997), 100:63-78. 